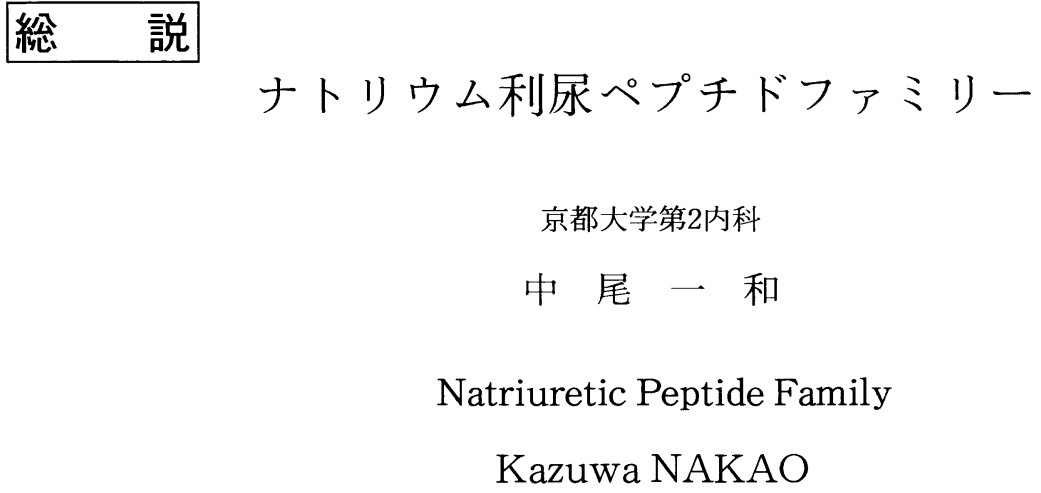

\author{
Second Division, Department of Medicine, \\ Kyoto University School of Medicine, Kyoto, Japan
}

The natriuretic peptide system consists of at least three endogenous ligands: atrial natriuretic peptide (ANP), brain natriuretic peptide (BNP) and C-type natriuretic peptide (CNP), and three receptors, ANP-A receptor (guanylate cyclase A), ANP-B receptor (guanylate cyclase B) and clearance receptor (C receptor).

ANP, the prototype of natriuretic peptides, is mainly produced in the atrium and secreted into the circulation as a cardiac hormone. ANP is also produced in the ventricle and in the central nervous system. BNP, first isolated from the porcine brain, has a marked divergence in its molecular size and sequence among species. In humans and rats, the major site of production of BNP is the ventricle of the heart. BNP is also secreted into the circulation as a cardiac hormone. The plasma BNP level in normal subjects is approximately one sixths of the plasma ANP level; however, the plasma BNP level markedly increases in heart failure, renal failure and hypertension and the augmentation of the BNP secretion is much larger than that of the ANP secretion. In addition, clearance of BNP from the circulation is slower than that of ANP. Furthermore, BNP is secreted more urgently than ANP in acute heart failure. CNP distributes mainly in the central nervous system and pituitary gland. No significant amount of CNP is detectable in the heart and plasma. Thus, CNP is a local regulator rather than a cardiac hormone.

Three natriuretic receptors have ligand selectivity. The rank order in potency for cyclic GMP production via ANP-A receptor is $A N P \geq B N P \gg C N P$, while that via ANP-B receptor is $\mathrm{CNP}>\mathrm{ANP} \geq \mathrm{BNP}$. The rank order of binding affinity for $\mathrm{C}$ receptor is ANP $>$ CNP $>$ BNP.

The complicated natriuretic peptide system is implicated in the control of body fluid and blood pressure in endocrine and paracrine fashions.

Key words : Atrial natriuretic peptide, Brain natriuretic peptide, $\mathrm{C}$-type natriuretic peptide, Natriuretic peptide receptor, Clearance receptor, Particulate guanylate cyclase 
は じめに

1983年の年末から1984年の初頭にかけての atrial natriuretic peptide (ANP) の単離構造決定の 報告以来 ${ }^{122}$, 血圧・体液量調節に関与する心臓ホルモンおよび神経ペプチドとしての ANP が注目 されてきたが ${ }^{3}$ ，1988年になりブタ脳より第2のナトリウム利尿ペプチドとして brain natriuretic peptide (BNP) か単離同定され，ナトリウム利尿ペプチドファミリーの存在が明らかになった1)。 一方, 受容体に関する研究も進展し, 1988年のクリアランス受容体のクローニングにつづいで 1989年には膜型グアニル酸シクラーゼそのものである2種類の受容体がクローニングされた (5)。 $^{5 / 2}$

更に1990年になり，松尾らにより第3のナトリウム利尿ペプチドである C-type ナトリウム利尿 ペプチド (CNP) がブタ脳より単離構造決定された7)。このようにナトリウム利尿ペプチドシステ ムは, 少なくとも3種類の内因性ペプチドと 3 種類の受容体より成る複雑且つ巧妙な血圧，体液量調 節系であり, 今後ナトリウム利尿ペプチドシステムの分子機構と生理的意義の解明, この成果を踏 まえた臨床応用の発展が期待される ${ }^{8)}$ 。

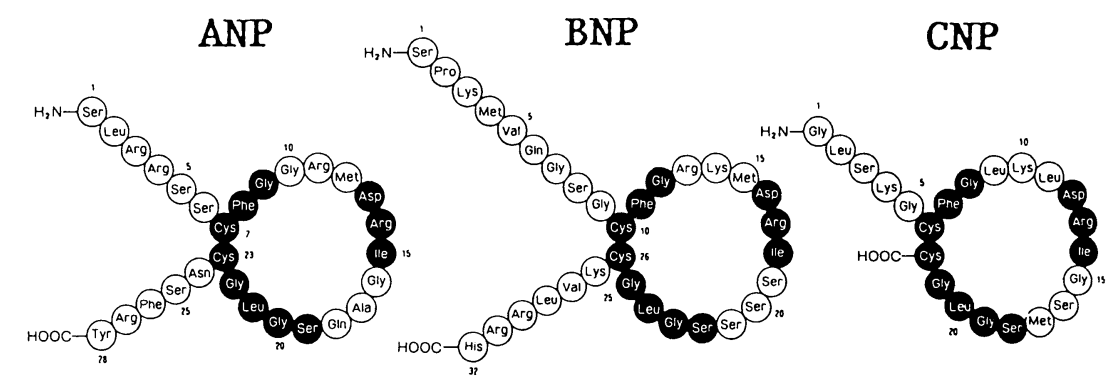

図1. ヒトのナトリウム利尿ペプチドファミリーの構造

\section{NATRIURETIC PEPTIDE FAMILY}
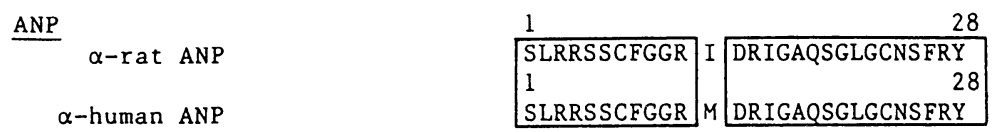

$\underline{B N P}$
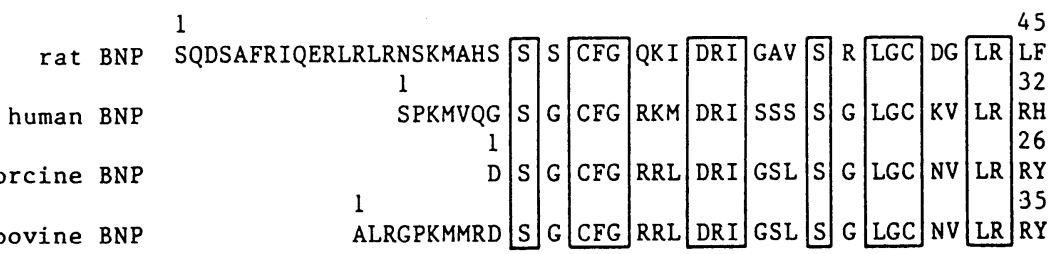

$\underline{\text { CNP }}$

CNP

1 GLSKGCFGLKLDRIGSMSGLGC

図2. ナトリウム利尿ペプチドファミリーの一次構造の種属差 
I ナトリウム利尿ペプチドファミリー

ANP (図1, 図2) ${ }^{122) 33}$

哺乳類の心臓ホルモンとしての $\alpha-\mathrm{ANP}$ は28アミノ酸より成っており，アミノ酸配列は 12 番目 を除いて完全に保存されている。ヒト，ウシ，ブタ，イヌ等では 12 番目のアミノ酸はメチオニンで

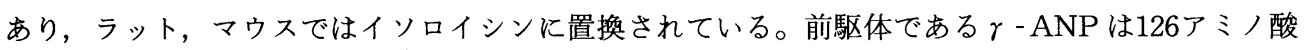
よりなり，心筋細胞の分泌顆粒中の貯蔵型であり，分泌の直前あるいは分泌中に $\alpha-\mathrm{ANP} に$ 変換 されると考兄られている。またヒトのみで $\alpha$ - ANP の逆平行2量体である $\beta$ - ANP が検出されてお り, 特に心不全で増加することが注目される。 $\beta$ - ANP は $\alpha$-ANP に変換されて作用すると考文 られている。

ANP は中枢神経系にも存在するが，神経ペプチドとして ANP は N 端部のアミノ酸の欠如した $\alpha$-ANP[4-28], $\alpha$-ANP[5-28]であり, 組織特異的なプロセッシング酵素が存在すると考兄ら れている3)。

ANP 生合成・分泌の主要組織は心房であり, 心房筋の伸展が主要な分泌刺激となる。正常心室 にも心房の 100 分の1程度の ANPmRNA が検出され心室でも ANP が生合成されるが，胎生期や新 生児期，並びに肥大心臓の心室筋細胞では ANP 生合成が充進していることが知られている。また， ラットでは第3脳室前腹側部 (anteroventral third ventricular region, AV3V region) 等に ANP 陽 性神経細胞の分布が明かにされており，中枢性体液量血圧調節に作用していると考えられている3

BNP（図1, 図2） ${ }^{118)}$

BNP は1988年ブタ脳より単離構造決定されたが，26アミノ酸より成る BNP-26に加え， N 端部 に6アミノ酸が延長した BNP-32が存在することが知られている。クローニングされたブタ BNP 前駆体は106アミノ酸より成るが, 2 力所で蛋白分解酵素の作用を受け BNP-32, BNP-26が生成 される。ブタBNPの脳内分布は ANP の脳内分布と明らかに異なることが知られている。また, その後の研究によりブタ BNPの組織濃度は脳より心臓で高濃度であること, 分泌型は低分子型の BNP-32, BNP-26であることが明らかになってきている。しかし，ANPの構造が哺乳類でよく 保存されているのと対照的に, BNPのアミノ酸配列と分子サイズは著しい種属差が存在するため, ブタ BNP に対する抗体はヒトやラットの BNP と交叉反応を示さず, 研究上の大きな妨げになっ ていた。

松尾ら著者らは，1989年にラットBNPを，1990年にヒトBNP の単離構造決定に成功したが， ラット BNP は45アミノ酸, ヒト BNPは32アミノ酸より成り, ナトリウム利尿ペプチド特有の環 状構造が著しく異なることが明らかになった（図2）。De Lean らにより報告されたウシ BNP は 35 ア 酸より成っており, 分子サイズも多様であることが注目される。前駆体のアミノ酸数も種 属差が著しく, ブタが106個であるのに対し，ラットでは95個，ヒトでは108個である。更に注目す ベきは生物活性に認められる種属差であり，ヒトBNPはラットに静脈内投与してもそのナトリウ ム利尿作用はラット BNP や ANP の数十分の一に過ぎず，またラット大動脈標本の弛緩活性も著 しく弱いが, ブタ冠動脈の驰緩活性はブタ BNP の10倍, ラットBNP の500倍であり, ANPより 強い。。ヒトBNPはヒトに投与した際には ANP と同等以上の生物作用を発揮することも明らかに されている ${ }^{10)}$ 。

ヒト BNP とラットBNPの単離同定により BNP 生合成や分泌に関する研究は急速に進展し, B NP はブタ脳より単離同定されたにもかかわらず，ヒトやラットの脳にはほとんど検出されないこ 
と ${ }^{11)}$, 組織中 BNP 濃度は心房で最も高濃度であるが, BNPmRNA 総量は心室で最大であり，七 トの心臓カラーラル検査時に得られた血漿サンプルの解析やラット心蔵の潅流実験の結果より血中 BNP の主要な分泌源は心室であることが証明されている ${ }^{1112}$ 。また, BNP の半滅期は ANP に比 較すると有意に大きく, BNP は ANPより long acting であり, この BNP の特徵もBNP の臨床 応用を期待されるものである ${ }^{12)}$ 。

以上より心蔵は主に心房より ANP, 主に心室より BNP を合成し, 各々心房, 心室に対する負荷 に応じて分泌すると考えられる。

CNP (図1, 図2) ${ }^{13)}$

CNP は，ブタ脳より単離同定された 22 個のアミノ酸から成る第3のナトリウム利尿ペプチドであ り，ナトリウム利尿ペプチドに共通のジスルフィド結合によって形成される環状部分を有するが, C 端部分への伸長が欠如している点が特徵的である゙（図1）。その後，ブタ脳より，N 端部が伸長 した53残基から成る CNP-53が単離され，ブタ脳内に拈ける主要な分子型として報告されている。 ブタ CNP 遺伝子, ラット CNPcDNA, ヒト CNP 遺伝子の構造解析が行われ, CNP の構造は, 七 ト,ブタ, ラットで完全に同一であり, CNP-53では, ブタとラットは同一でヒトでは2箇所アミ ノ酸が異なることが明らかにされた ${ }^{13)}$ 。

このように CNP 構造は種を越えて保存されており, 多様な分子型を示す BNP とは極めて対照 的である。また CNP-53は CNP と同様に生物活性を有することが知られている。著者らは, 最 近, CNP に対する RIA を開発しラットの体内分布およびヒト脳内における CNP の分布を検討し た ${ }^{14)}$ 。ラットにおいては CNPは，下垂体において最も高濃度検出され（前葉＞後葉）, 脳内各部 位にも広範に分布していた。腸管，腎においてもわずかに検出されたが，心臟を含む他組織では検 出されなかった。これらの結果は, ラット各組織におけるCNP 遺伝子発現を Northern blot 法に て検討し，脳においてのみ mRNA が検出されたことと合致するものである。表1には，ヒト脳内 各部におけるナトリウム利尿ペプチドの分布を示すが, CNP は, ヒト脳内各部位に広く分布し, 視床下部・視床・中脳・延喵道に掞いて高濃度検出され, 同時に測定した ANP, BNP 濃度の10倍以 上であり，CNPがヒト脳内の主要なナトリウム利尿ペプチドであることが示唆された。また CNP はヒトの脳脊䯣液中にも検出され，その濃度は ANP, BNP 濃度より高値を示す。以上の成績より CNP は ANP や BNP とは異なり神経ペプチドあるいは, 局所因子として作用していると考えら れる。

ヒト血液中のナトリウム利尿ペプチドファミリー

図3には正常血中 ANP, BNP 濃度と心不全, 腎不全, 本態性高血圧症, 内分泌性高血圧患者の 血中濃度を示している ${ }^{15)}$ 。ヒトの正常血中 BNP 濃度は平均 $0.9 \mathrm{fmol} / \mathrm{ml}$ 位であり, 同時に測定した ANP 濃度の6分の1程度であるが, 重症心不全では基礎值の100倍以上の増加を示し, ANPより高 值を示す場合も多い。腎不全や高血圧でも BNPの基礎值よりの増加率は ANPより大きく，心室 での生合成・分泌の充進とクリアランスされにくい性質によると考えられている。また最近, 著者 らは急性心筋硬塞による急性心不全患者に招いて血中 BNP 濃度は発作後数時間以内に著しい増加 を示すことを報告した ${ }^{16)}$ 。心蔵は急性心筋硬塞に代表される緊急事態には心室での BNP 生合成と 分泌が充進することを示唆しており, 更に検討を進めている。心蔵は主に心房より ANP, 心室よ り BNP を分泌していることは既に述べたが，2種類の心蔵ホルモンの存在する生理的・臨床的意 義の解明が期待される。 
表1. ヒトの脳におけるナトリウム利尿ペプチドファミリーの分布

\begin{tabular}{|c|c|c|c|}
\hline Brain regions & CNP-LI & ANP-LI & BNP-LI \\
\hline $\begin{array}{l}\text { Cerebral } \\
\text { cortex }\end{array}$ & 0.61 & $<0.07$ & $<0.06$ \\
\hline Thalamus & 2.90 & $<0.07$ & $<0.06$ \\
\hline Hypothalamus & 4.02 & 0.13 & $<0.06$ \\
\hline Midbrain & 3.28 & $<0.07$ & $<0.06$ \\
\hline Pons & $<0.40$ & 0.15 & $<0.06$ \\
\hline $\begin{array}{l}\text { Medulla } \\
\text { oblongata }\end{array}$ & 2.78 & 0.08 & $<0.06$ \\
\hline $\begin{array}{l}\text { Cerebellum } \\
\text { (cortex) }\end{array}$ & 0.85 & $<0.07$ & $<0.06$ \\
\hline
\end{tabular}

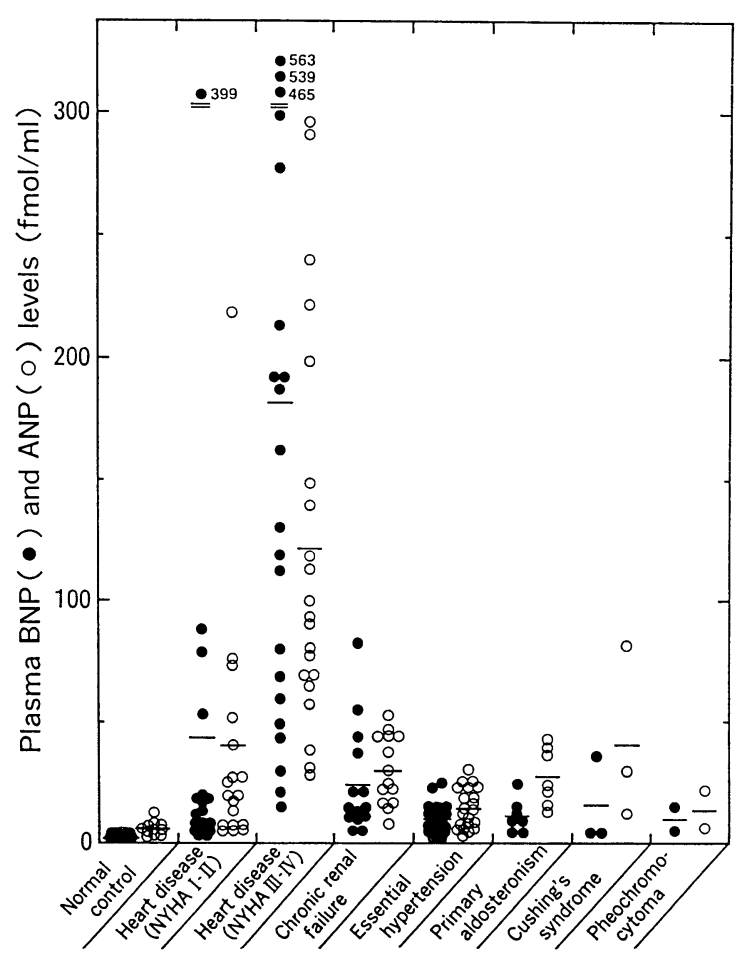

図3．ヒト血液中の ANP, BNP 濃度 


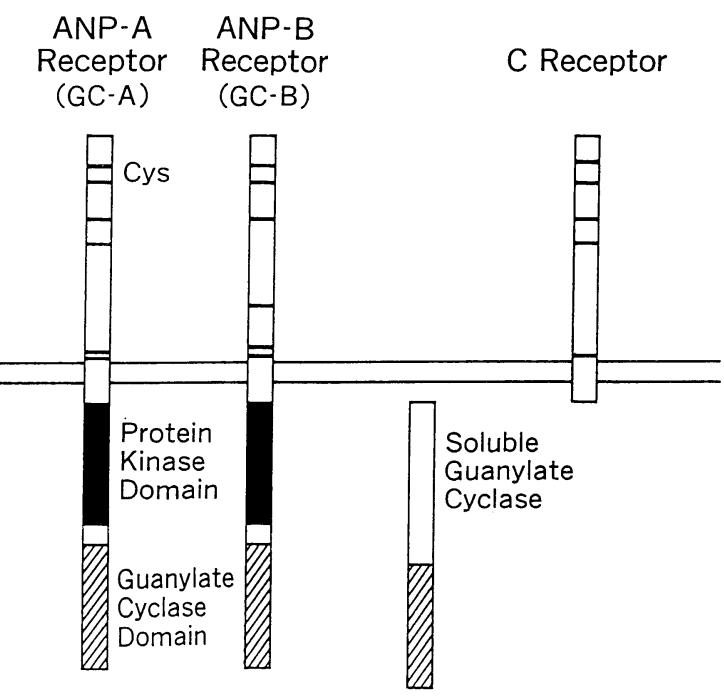

図4．ナトリウム利尿ペプチド受容体の構造

\section{II ナトリウム利尿ペプチド受容体 ${ }^{17)}$}

ナトリウム利尿ペプチド受容体については, 結合実験と cyclic GMP 産生能の研究により, 膜型 グアニル酸シクラーゼと共役し, 生物作用に関与する受容体（Biologically Active Receptor, B 受 容体）とグアニル酸シクラーゼとは共役せず, クリアランスのみに関与するクリアランス受容体 (Clearance Receptor, C 受容体) の存在が提唱されてきた ${ }^{18)}$ として実際にウシの血管平滑筋の C受容体の全構造がクローニングされだ)。

1989年には，ウ二の精子のリサクト受容体の研究に端を発したラットの膜型グアニル酸シクラー ゼのクローニングが行われ, 膜型グアニル酸シクラーゼそのものが ANP 受容体であることが証明 された市。更にその後, 基本構造の類似した異なる受容体がヒト胎盤 cDNA ライブラリーよりクロー ニングされた。この受容体は ANP よリブタ BNP の方が cyclic GMP 産生能が強いことが報告さ $れ^{6}$, 前者は $\mathrm{ANP}-\mathrm{A}$ 受容体あるいはGC-A, 後者は $\mathrm{ANP}-\mathrm{B}$ 受容体あるいは $\mathrm{GC}-\mathrm{B}$ と命名さ れた。戝4に3種類の受容体の構造を模式的に示している。3種類の受容体は1回膜貫通型であるが ${ }^{17}$, 最初にクローニングされた C 受容体は細胞内ドメインは37アミノ酸よりなるのみであり細胞内情 報伝達機構を持たないと考穴られている゙〉。しかし，サイトカイン受容体のように他の蛋白質と共 役して情報伝達を行う可能性も残されている。C受容体はホモダイマーとして存在している。現在 までのところ，C受容体のサブタイプの存在は明らかにされていない。

$\mathrm{ANP}-\mathrm{A}$ 受容体と ANP-B 受容体はその基本構造は極めて類似しており，ナトリウム利尿ペプ チドの結合する細胞外ドメインとプロテインキナーゼドメイン，グアニル酸シクラーゼドメインよ りなる細胞内ドメインを有する。グアニル酸シクラーゼ構造を含む細胞内ドメインの相同性は極め て高く, 対照的にリガンド選択性に関与する細胞外ドメインの相同性は相対的に低い。プロテイン キナーゼドメインの deletion mutant をCos7 細胞に発現させると cyclic GMP 産生が 
constitutive に活性化されることが明らかになり，このドメインはグアニル酸シクラーゼ活性を抑 制的に調節していることが示唆されている年市。またATPによるグアニル酸シクラーゼの活性化は このプロテインキナーゼドメインへの ATP の結合によって起ると考えられている ${ }^{17)} 。$

$\mathrm{ANP}-\mathrm{A}$ 受容体, ANP-B受容体の細胞内ドメインのプロテインキナーゼドメインに続く $\mathrm{C} 末$ 端に存在するグアニル酸シクラーゼドメインはアデニル酸シクラーゼとの相同性が知られているが 実際に cyclic GMP 産生に与ることが証明されている ${ }^{17) 。 ~}$

表2．ナトリウム利尿ペプチド受容体のリガンド選択性

\begin{tabular}{ll}
\hline $\mathrm{ANP}-\mathrm{A}$ 受容体 & $\mathrm{ANP} \geq \mathrm{BNP} \gg \mathrm{CNP}$ \\
$\mathrm{ANP}-\mathrm{B}$ 受容体 & $\mathrm{CNP}>\mathrm{ANP} \geq \mathrm{BNP}$ \\
クリアランス受容体 & $\mathrm{ANP}>\mathrm{CNP}>\mathrm{BNP}$ \\
\hline
\end{tabular}

\section{III ナトリウム利尿ペプチド受容体のリガンド選択性 ${ }^{1920)}$}

ナトリウム利尿ペプチドファミリーの作用を解明するためには，これまで述べてきた 3 種類の受 容体, 即ち ANP-A 受容体, ANP-B 受容体, C 受容体のリガンド選択性を明らかにすることが 重要である。この際に充分に留意すべきことは，BNP の一次構造に著しい種属差が存在すること であり, in vivo や in vitroの bioassay 標本としてどの種属を用いるかで生物作用が大きく異なる ことは既に述べた通りである。従ってナトリウム利尿ペプチド受容体のリガンド選択性を解明する ためには，同種属の受容体とリガンドを用いることが不可欠である。表 2 にヒトとラットにおい て著者らが検討した3受容体のリガンド選択性をまとめて示している ${ }^{19)}$ 。同種属の受容体とリガン ドを用いて検討するとヒトとラットで本質的に同一の選択性が認められ，ANP-A 受容体におい ては ANP が最も強力に cyclic GMP 産生を刺激し，BNP は ANP に次いで cyclic GMP 産生を刺 激することが明らかになった。しかし CNP は ANP の103分の1以下の cyclic CMP 産生しか示さず 生理的には ANP-A 受容体には作用しないと考えられる。一方, ANP-A 受容体とは対照的に ANP-B 受容体は CNPにより最も強力に cyclic GMP 産生が促進され，ANP，BNP の作用は弱 い。ヒト ANP-B受容体とブタ BNPを用いて検討された当初の研究ではブタ BNPが例外的に $\mathrm{A}$ NP－B 受容体の cyclic GMP 産生を刺激したため, ANP-B 受容体はBNPの受容体として報告 されていたが，実際には CNP の受容体であると考えられる。結合実験で C 受容体に対する親和性 を検討すると ANP が最も高い親和性を示したが，BNP の親和性は低く ANP の10分の1以下であっ た。この結果はBNPのクリアランスが ANPに比較して遅いこととょく一致している。以上述べ た3種類のナトリウム利尿ペプチド受容体のリガンド選択性はヒトの受容体を Cos7細胞に発現させ て検討した Koller らの成績とよく一致している ${ }^{20)}$ 。

我々はラットにおいて BNP を静脈内に投与するとANP の約 2 倍の利尿作用や降圧作用を観察し ており9)，またヒトにおいても BNP 投与は少なくともANP と同等の作用を示すことを報告してい $3^{10)}$ 。これらの結果は ANP-A 受容体と ANP-B 受容体のリガンド選択性では説明が困難であり, i）BNP 選択性の未知の受容体が存在する可能性 ii）BNP はC 受容体への親和性が低いので代謝 されにくく，ANP-A 受容体を介する作用が in vivoでは in vitro より相対的に強く現われる可能 性 iii）ANP，BNP，CNP が代謝酵素である Neutral Endopeptidase に対する親和性においても 異なっている可能性, 等が考学られる。今後の研究の進展が期待される。 
最近 Garbers らは第3の膜型グアニル酸シクラーゼをラット小腸の cDNA ライブラリーよりクロー ニングしたが，この酵素 $(\mathrm{GC}-\mathrm{C})$ はナトリウム利尿ペプチド受容体と基本構造は類似しているに もかかわらず，ナトリウム利尿ペプチドとは反応せず，大腸菌のエンテロトキシンの受容体である と報告されている ${ }^{17)}$ 。この新しい受容体の内因性リガンドは不明であるが，この発見は膜型グア二 ル酸シクラーゼはナトリウム利尿ペプチドファミリーに特異的な受容体のみではないことを示唆し ている。

おわりに

ナトリウム利尿ペプチドファミリーとその受容体に関する研究の最近の進歩について概説した。 少なくとも3種類の内因性ペプチドと 3 種類の受容体よりなるナトリウム利尿ペプチドシステムは, 1 種類の内因性リガンドと1種類の受容体のみよりなる単純な生体調節システムと比較し, 複雑な分 子機構の存在する故の巧妙な生理的役割を果している可能性が強い。更に, 第4のナトリウム利尿 ペプチドの存在する可能性, BNP 選択性受容体の存在の可能性等が示唆されており, 今後の研究 の発展が期待される。また，この複雑な分子機構の解明はナトリウム利尿ペプチドファミリーの臨 床応用を更に発展させるものと期待される。紙面の都合により生理作用に関しては割愛させていた だいた。

\section{文献}

1 ) 松尾壽之, 寒川賢治, 南野直人：ナトリウム利尿ホルモンファミリー・蛋白質・核酸・酵素 $1988 ; 33: 2438-2450$

2 ) de Bold AJ Atrial natriuretic factor: a hormone produced by the heart. Science 1985; 230: $767-770$

3 ) 中尾一和，井村裕夫：ANP の生合成と分泌・蛋白質・核酸・酵素 1988；33：2461-2480

4 ) Fuller F, Porter JG, Arfsten AE, Miller J, Schilling JW, Scarborough RM, Lewicki JA, Schenk DB Atrial natriuretic peptide clearance receptor. J Biol Chem 1988; 263: 9395-9401

5 ) Chinkers M, Garbers DL, Chang MS, Lowe DG, Chin H, Goeddel DV, Schulz S A membrane form of guanylate cyclase is an atrial natriuretic peptide receptor. Nature 1989; 338: 78-83

6) Chang MS, Lowe DG, Lewis M, Hellmiss R, Chen E, Goeddel DV Differential activation by atrial and brain natriuretic peptides of two different receptor guanylate cyclases. Nature 1989; 341: 68-72

7 ) Sudoh T, Minamino N, Kangawa K, Matsuo H C-type natriuretic peptide (CNP): a new member of natriuretic peptide family identified in porcine brain. Biochem Biophys Res Commun 1990; 168: 863-870

8 ）中尾一和：ナトリウム利尿ペプチドファミリーー最近の進歩一・最新医学 1991；46: 10-15

9 ) Kambayashi Y, Nakao K, Kimura H, Kawabata T, Nakamura M, Inouye K, Yoshida $\mathrm{N}$, Imura $\mathrm{H}$ Biological characterization of human BNP and rat BNP - species-specific actions of BNP-Biochem Biophys Res Commun 1991; 173: 599-605

10) M. Yoshimura, H. Yasue, E. Morita, N. Sakaino, M. Jougasaki, M. Kurose, M. 
Mukoyama, Y. Saito, K. Nakao, H. Imura: Hemodynamic, renal, and hormonal responses to brain natriuretic peptide infusion in patients with congestive heart failure. Circulation 1991; 84: 1581-1588

11) Ogawa $Y$, Nakao K, Mukoyama M, Shirakami G, Itoh H, Hosoda K, Saito Y, Arai H, Suga S, Jougasaki M, Yamada $T$, Kambayashi $Y$, Inouye $K$, Imura $H$ Rat brain natriuretic peptide-Tissue distribution and molecular form-Endocrinology 1990; 126: $2225-2227$

12) Mukoyama M, Nakao K, Hosoda $K$, Suga S, Saito $Y$, Ogawa $Y$, Shirakami G, Jougasaki M, Obata $\mathrm{K}$, Yasue $\mathrm{H}$, Kambayashi $\mathrm{Y}$, Inouye $\mathrm{K}$, Imura $\mathrm{H}$ : Brain natriuretic peptide (BNP) as a novel cardiac hormone in humans-Evidence for an exquisite dual natriuretic peptide system, atrial natriuretic peptide and brain natriuretic peptide-J Clin Invest $1991 ; 87: 1402-1412$

13）南野直人, 松尾壽之, 児島将康, 寒川賢治 : 新しいナトリウム利尿ペプチド : CNP ・実験医 学 1990; 8: 2359-2366

14) Komatsu $Y$, Nakao K, Suga S, Ogawa $Y$, Mukoyama M, Arai H, Shirakami G, Hosoda K, Nakagawa O, Hama N, Kishimoto I, Imura H $1991 \mathrm{C}$-type natriuretic peptide (CNP) in rats and humans. Endocrinology 1991; 129: 1104-1106

15) Mukoyama M, Nakao K, Saito Y, Ogawa Y, Hosoda K, Suga S, Shirakami G, Jougasaki $\mathrm{M}$, Imura $\mathrm{H}$ Human brain natriuretic peptide, a novel cardiac hormone. Lancet 1990; 335: 801-802

16) M. Mukoyama, K. Nakao, K. Obata, M. Jougasaki, M. Yoshimura, E. Morita, K. Hosoda, S. Suga, Y. Ogawa, H. Yasue, H. Imura: Augmented secretion of brain natriuretic peptide in acute myocardial infarction. Biochem Biophys Res Commun 1991; 180: $431-436$

17) Chinkers M, Garbers DL: Signal transduction by guanylyl cyclases. Annu Rev Biochem 1991; 60: 553-575

18) Maack T, Suzuki M, Almeida FA, Nussenzveig D, Scarborough RM, McEnroe GA, Lewicki JA Physiological role of silent receptors of atrial natriuretic factor. Science 1987; 238: 675-678

19) Suga S, Nakao K, Hosoda K, Mukoyama M, Ogawa Y, Shirakami G, Arai H, Saito Y, Kambayashi $\mathrm{Y}$, Inouye K, Imura H: Receptor selectivity of natriuretic peptide family, atrial natriuretic peptide, brain natriuretic peptide, and $\mathrm{C}$-type natriuretic peptide. Endocrinology 1992; 130: 229-239

20) Koller KJ, Lowe DG, Bennett GL, Minamino N, Kangawa K, Matsuo H, Goeddel DV: Selective activation of the $\mathrm{B}$ natriuretic peptide receptor by $\mathrm{C}$-type natriuretic peptide (CNP). Science (Wash DC) 1991; 252: 120-123 